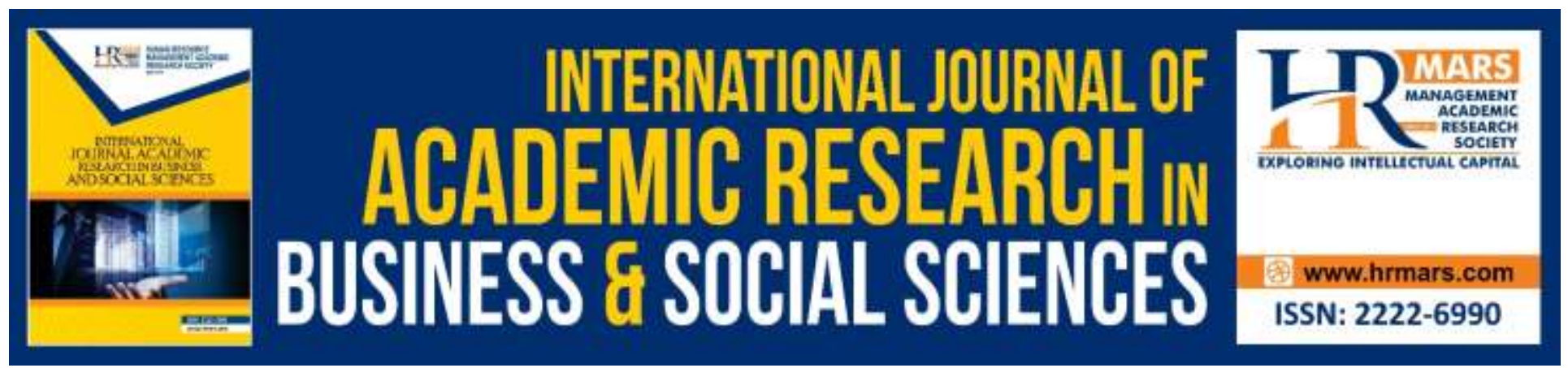

\title{
The Relationship between Halal Food Management System Critical Constructs Implementation, Operational Performance and Product Quality
}

Ahmad, A. N., Rahman, R. A., Othman, M., Che Ishak, F. A., Mohamad, S. F., Abidin, U. F. U. Z.

To Link this Article: http://dx.doi.org/10.6007/IJARBSS/v10-i3/7096 DOI:10.6007/IJARBSS/v10-i3/7096

Received: 08 February 2020, Revised: 26 February 2020, Accepted: 13 March 2020

Published Online: 26 March 2020

In-Text Citation: (Ahmad et al., 2020)

To Cite this Article: Ahmad, A. N., Rahman, R. A., Othman, M., Che Ishak, F. A., Mohamad, S. F., \& Abidin, U. F. U. Z. (2020). The Relationship between Halal Food Management System Critical Constructs Implementation, Operational Performance and Product Quality. International Journal of Academic Research in Business and Social Sciences, 10(3), 836-854.

Copyright: (c) 2020 The Author(s)

Published by Human Resource Management Academic Research Society (www.hrmars.com)

This article is published under the Creative Commons Attribution (CC BY 4.0) license. Anyone may reproduce, distribute, translate and create derivative works of this article (for both commercial and non-commercial purposes), subject to full attribution to the original publication and authors. The full terms of this license may be seen at: http://creativecommons.org/licences/by/4.0/legalcode

Vol. 10, No. 3, 2020, Pg. 836 - 854

http://hrmars.com/index.php/pages/detail/IJARBSS

JOURNAL HOMEPAGE

Full Terms \& Conditions of access and use can be found at http://hrmars.com/index.php/pages/detail/publication-ethics 


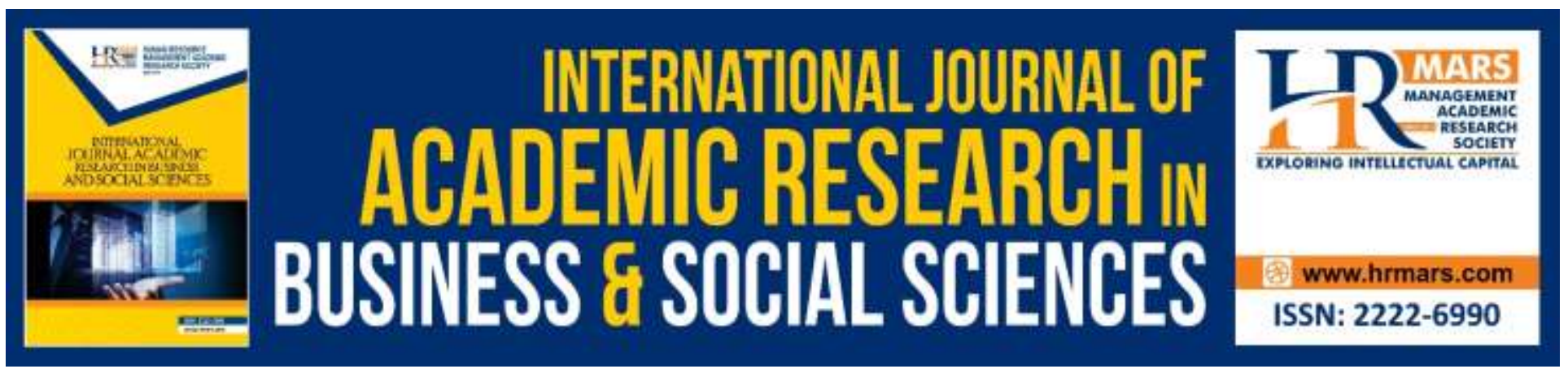

\title{
The Relationship between Halal Food Management System Critical Constructs Implementation, Operational Performance and Product Quality
}

\author{
Ahmad, A.N ${ }^{1,3}$, Rahman, R.A ${ }^{1,2}$ Othman, M. ${ }^{1,2}$ Che Ishak, F. A. ${ }^{2}$ \\ Mohamad, S. F., ${ }^{2}$ Abidin, U.F.U.Z. ${ }^{1,2}$ \\ ${ }^{1}$ Halal Products Research Institute, Universiti Putra Malaysia, 43400 UPM, Serdang, Selangor, \\ Malaysia, ${ }^{2}$ Department of Food Service and Management, Faculty of Food Science and Technology, \\ Universiti Putra Malaysia, 43400 UPM, Serdang, Selangor, Malaysia, ${ }^{3}$ International Institute for \\ Halal Research and Training (INHART), International Islamic University Malaysia, 53100 Jalan \\ Gombak, Selangor, Malaysia
}

\begin{abstract}
Given the limited studies on Halal food management system, this study seeks to assess the relationship between the implementation of Halal food management system critical constructs, operational performance and product quality. A total of 163 samples collected from Halal certified SMEs manufacturers in Malaysia were used for data analysis. Data were initially subjected to exploratory factor analysis (EFA) to identify the underlying constructs. Partial least squares (PLS) was then used to examine the extent to which implementation of halal food management system critical constructs influence operational performance and product quality. The results showed that not all critical constructs were directly and positively associated with organisational performance and product quality. The lack of significant relationships between critical constructs and performance constructs are intriguing and should be an impetus for further investigations into potential contingencies and indirect associations of Halal food management system critical constructs on performance constructs. In addition, rather than a piecemeal approach, companies may need to holistically and systemically implement all the Halal food management system critical constructs.
\end{abstract}

Keyword: Halal Food, Food Manufacturer, Halal Food Certification, SMEs

\section{Introduction}

Companies often implement a management system to gain a competitive advantage over others, win customer loyalty, gain business resources, or obtain massive funding (Douglas \& Judge, 2001). According to Kafetzopoulos and Gotzamani (2014), the ultimate aim for quality and food safety management system implementation is to improve the overall business performance. In fact, few studies have reported that after the implementation of food safety management system, companies 
INTERNATIONAL JOURNAL OF ACADEMIC RESEARCH IN BUSINESS AND SOCIAL SCIENCES Vol. 10, No. 3, March, 2020, E-ISSN: 2222-6990 @ 2020 HRMARS

have experienced both internal and external benefits such as improvement in term of product traceability, food safety awareness of employees, customers satisfaction, and decreased in the wastage cost and customer complaints (Carmen \& Santos-Vijande, 2014; Chen et al., 2015).

The ultimate objective of Halal food management system, on the other hand is to ensure the Halal and Toyyib status of the products. However, multiple authors argued that industry could also use Halal food management system as a mechanism to improve their performance, in term of logistics, overall management, market entry, market share, market expansion, sales, revenue, market or industry growth, customer retention, consumer confidence and satisfaction (Talib, Abdul Hamid, et al., 2016). Most authors, however, provided only anecdotal evidence that relate Halal management system with performance, except for few studies. Some of the exceptions is a study by Razalli et al. (2013) who assessed the direct relation between 12 Halal management system constructs (Halal documentation, management responsibility, raw material, location, exterior area, premise, facility, tools and equipment, staff characteristic, staff policy, pest control, and waste management) and hotel performance. They found that only facilities and staff policy had positive and significant influence on the overall hotel performance. In another study, Othman et al. (2017) assessed the direct influence of three Halal-related constructs (knowledge, attitude, sensitivity toward government Halal policies) on organizational performance. The authors found that all the constructs had positive and significant relationships. In contrast to previous two studies, Talib, Ai Chin and Fischer (2017) conceptualized Halal food management system (human resource, infrastructure and equipment, production process, marketing function, and logistics and distribution) as a single construct. Talib, Ai Chin and Fischer (2017) found the positive linkage between Halal constructs, operational and financial performance constructs. Talib et al. (2017) however operationalized Halal food management system as a single construct. Compared to single construct approach, the multi-dimensional approach allows a deeper insight of value and role of each Halal food management system critical constructs (Samson \& Terziovski, 1999). Therefore, a multi-dimensional operationalization of Halal food management system critical construct and organisational performance is considered in this study. In brief, this study aims to assess the direct relationship between Halal food management system critical constructs, operational performance and product quality.

\section{Literature Review}

Compared to Halal food and food safety management system, the relationships between effective management practices and performance have been more extensively studied in quality management literature. In general, the previous studies have provided different sets of quality management constructs considered as essential to the success of quality management implementation. Common quality management constructs include leadership, training, employee management, information and analysis, supplier management, process management, customer focus, and continuous improvement (Sadikoglu \& Zehir, 2010; Sila, 2007). Different ways have been proposed to measure organisational performance such as through financial performance, non-financial performance, operational performance, innovation performance, quality performance, as well as product/service quality (Brah, Tee, \& Rao, 2002; Garvin, 1987; Psomas, Pantouvakis, \& Kafetzopoulos, 2013; Samson \& Terziovski, 1999; Sousa \& Voss, 2002).

While some studies have found evidence pointing towards mixed association between quality management implementation and performance (Brah, Li Wong, \& Madhu Rao, 2000; Kaynak, 2003; 
INTERNATIONAL JOURNAL OF ACADEMIC RESEARCH IN BUSINESS AND SOCIAL SCIENCES Vol. 10, No. 3, March, 2020, E-ISSN: 2222-6990 @ 2020 HRMARS

Prajogo \& Sohal, 2003; Psomas \& Jaca, 2016), in general, previous researchers have highlighted the positive relationships between quality management implementation constructs and organisational performance (Anderson et al., 1994; Choi \& Eboch, 1998; Das et al., 2000; Douglas \& Judge, 2001; Flynn et al., 1995; Ho et al., 2001; Kaynak, 2003; Shah \& Ward, 2007). Previous studies have demonstrated that companies who have effectively implemented their quality and food safety management systems have experienced positive and significant improvement in term of product quality (Aggelogiannopoulos, Drosinos, \& Athanasopoulos, 2007; Khatri \& Collins, 2007; Liao, Enke, \& Wiebe, 2004; Scott, Wilcock, \& Kanetkar, 2009; Semos \& Kontogeorgos, 2007; Trienekens \& Zuurbier, 2008) and operational performance (Feng, Terziovski, \& Samson, 2008; Jang \& Lin, 2008; Koc, 2007; Magd, 2006).

As there is no detailed analysis of the relationship between each Halal food management system implementation constructs and performance in the prior literature, this study relies on the argument that proposes positive and direct relationship between management system critical constructs and organisational performance. Additionally, given that the present study is an exploratory in nature whereby qualitative approach (Ahmad, Abdul Rahman, Othman, \& Ungku Zainal Abidin, 2017) is initially taken to develop instrument, hypotheses for each Halal food management system critical constructs are not pre-specified prior to EFA (Annear et al., 2015; Dow, Samson, \& Ford, 1999; Harrington, 2009; Psomas \& Jaca, 2016). Thus, the main research hypotheses are formulated as the following:

$\mathrm{H1}$ : Each of the Halal food management system critical construct is positively related to operational performance

$\mathrm{H} 2$ : Each of the Halal food management system critical construct is positively related to product quality.

\section{Materials and Methods Survey Design}

Questionnaire encompassing two sections was developed as the instrument for this study. Section 1 contains statements about implementation of critical factors in halal food management system ( $n=57$ items), operational performance ( $n=10$ items) and product quality ( $n=4$ items). Questions about critical factors in halal food management system were developed from findings from semi-structured interviews that were previously conducted (Ahmad et al., 2017). Ten critical Halal food management constructs identified in semi-structured interviews are - consumer focus; employee management and characteristics; teamwork; Halal personnel empowerment; information capacity; adequate support; top management commitment; training; policy and procedure; supplier management. Constructs of operational performance and product quality were adapted from Kafetzopoulos and Gotzamani (2014) who studied the impact of effective food safety and quality management system implementation on organisational performance. Some of the independent constructs (e.g. organisational attributes, employee attributes and system requirements) in study by Kafetzopoulos and Gotzamani (2014) were also similar with the construct identified in the semi-structured interviews. Subjective measures were used to assess organisational performance (operational performance and product quality). Despite some drawbacks (susceptibility to common source bias and social desirability) (Bedi, 2016), previous studies have revealed that the subjective measure is a good proxy of real organizational performance due to strong correlations between subjective and 
INTERNATIONAL JOURNAL OF ACADEMIC RESEARCH IN BUSINESS AND SOCIAL SCIENCES

Vol. 10, No. 3, March, 2020, E-ISSN: 2222-6990 @ 2020 HRMARS

objective performance data. The respondents' perception on their companies performance was also often consistent with the actual performance of the organisation (Bedi, 2016; Dess \& Robinson Jr, 1984; Wall et al., 2004). Likert scale ranging from 1 (strongly disagree) to 7 (strongly agree) were used for this section. In the second section, questions on respondent's demographic and company information were included.

\section{Data Collection}

The target population for this study was SMEs Halal food companies certified under the category of food and beverage products. The eligibility criterion specified was that the respondent is either the Halal executive or a part of their companies' internal Halal committee. A mixed-mode surveys (penand-paper and online questionnaires) was used to maximize responses (Dillman et al., 2009). First, pen-and-paper questionnaires were distributed to SMEs Halal certified food companies attending HalFest 2016 on $31^{\text {st }}$ August to $4^{\text {th }}$ September 2016. A useful sample of 106 respondents was obtained. Additionally, the invitations to participate the study were sent via email to a sample of selected SMEs food companies from those recorded in JAKIM directories. 75 valid questionnaires were received via this mode. A total of 181 complete responses were received from both modes of data collection. In both survey modes, respondents were assured of total confidentiality and anonymity.

\section{Data Analysis}

Mahalanobis distances $\left(D^{2}\right)$ test was used to identify the outliers. About 18 outlying cases were removed (Hair, et al., 2005); only 163 responses were used for the subsequent analysis. EFA was performed as the first step to uncover the underlying structure of Halal food management system construct. Non-parametric test of Spearman correlation was used to test the correlations among Halal food management system constructs. Then, the proposed model was examined using structural equation modelling (SEM) approach, SmartPLS 3.0. First, the measurement model (CFA) was evaluated to confirm the construct validity and reliability of the hypothesized model developed from EFA (Annear et al., 2015; Harrington, 2009). The structural model was examined afterwards to test the proposed hypotheses. Assessment of the structural relationship between the constructs using SEM is superior to regression analysis (Bouranta, Psomas, \& Pantouvakis, 2017).

\section{Specific Research Hypotheses}

The EFA result in the establishment of nine Halal food management system critical constructs, labelled as follows: consumer focus; employee attributes and management; teamwork; Halal personnel empowerment; information capacity; management and environment support; training, policy and procedure; supplier management; supplier assessment. Based on the EFA results, specific hypotheses were proposed as follows:

$\mathrm{H} 1_{\mathrm{a}} \quad$ Management and environmental support has a positive influence on operational performance. 
INTERNATIONAL JOURNAL OF ACADEMIC RESEARCH IN BUSINESS AND SOCIAL SCIENCES Vol. 10, No. 3, March, 2020, E-ISSN: 2222-6990 @ 2020 HRMARS

\begin{tabular}{|c|c|}
\hline $\mathrm{H} 2 \mathrm{a}$ & $\begin{array}{l}\text { Management and environmental support has a positive influence on } \\
\text { product quality }\end{array}$ \\
\hline$H 1_{b}$ & $\begin{array}{l}\text { Consumer focus has a positive influence on operational } \\
\text { performance. }\end{array}$ \\
\hline $\mathrm{H} 2_{\mathrm{b}}$ & Consumer focus has a positive influence on product quality \\
\hline $\mathrm{H} 1_{c}$ & $\begin{array}{l}\text { Employee attributes and management has a positive influence on } \\
\text { operational performance }\end{array}$ \\
\hline $\mathrm{H} 2_{\mathrm{c}}$ & $\begin{array}{l}\text { Employee attributes and management has a positive influence on } \\
\text { product quality }\end{array}$ \\
\hline$H 1_{d}$ & Teamwork has a positive influence on operational performance \\
\hline $\mathrm{H} 2 \mathrm{~d}$ & Teamwork has a positive influence on product quality \\
\hline $\mathrm{H} 1_{\mathrm{e}}$ & $\begin{array}{l}\text { Information capacity has a positive influence on operational } \\
\text { performance }\end{array}$ \\
\hline $\mathrm{H} 2_{\mathrm{e}}$ & Information capacity has a positive influence on product quality \\
\hline $\mathrm{H} 1_{f}$ & $\begin{array}{l}\text { Training, policy and procedure has a positive influence on } \\
\text { operational performance }\end{array}$ \\
\hline$H 2_{f}$ & $\begin{array}{l}\text { Training, policy and procedure has a positive influence on product } \\
\text { quality }\end{array}$ \\
\hline $\mathrm{H} 1_{\mathrm{g}}$ & $\begin{array}{l}\text { Halal personnel empowerment has a positive influence on } \\
\text { operational performance }\end{array}$ \\
\hline $\mathrm{H} 2 \mathrm{~g}$ & $\begin{array}{l}\text { Halal personnel empowerment has a positive influence on product } \\
\text { quality }\end{array}$ \\
\hline $\mathrm{H} 1_{h}$ & $\begin{array}{l}\text { Supplier management has a positive influence on operational } \\
\text { performance }\end{array}$ \\
\hline $\mathrm{H} 2 \mathrm{~h}$ & Supplier management has a positive influence on product quality \\
\hline$H 1_{i}$ & $\begin{array}{l}\text { Supplier assessment has a positive influence on operational } \\
\text { performance }\end{array}$ \\
\hline $\mathrm{H} 2_{\mathrm{i}}$ & Supplier assessment has a positive influence on product quality \\
\hline
\end{tabular}

\section{Results and Discussion}

\section{Demographic Information of Respondents}

Table 1 presents the profile of the companies participated in the study. Of the 163 sample food companies, $5.5 \%(n=9)$ companies had acquired Halal certification for less than 1 years prior, 33.7\% $(n=55)$ companies $1-3$ years prior, $16 \%(n=26)$ companies $4-6 y e a r s$ prior, $19 \%(n=31)$ companies $7-10$ years prior, and the remainder for more than ten years $(17.2 \%, n=28)$. Besides Halal, more than half of the companies (59.5\%, $n=97)$ were certified with MeSTI. More companies implemented HACCP/ISO 2200 (34.4\%, $n=56)$ compared to ISO 9001 (20.9\%, n=34). A total of 15.3\% $(n=25)$ companies had between 1-5 employees, 63.2\% ( $n=103)$ had $5-75$ employees and $21.5 \%(n=35)$ of them have more than 75 employees. Most companies surveyed (43.6\%) mainly produced less than 10 products. Only $14.1 \%$ produced more than 100 products. 
INTERNATIONAL JOURNAL OF ACADEMIC RESEARCH IN BUSINESS AND SOCIAL SCIENCES

Vol. 10, No. 3, March, 2020, E-ISSN: 2222-6990 C 2020 HRMARS

Table 1: Companies Profiles

\begin{tabular}{lll}
\hline Variable & Frequency (n) & Percent (\%) \\
\hline Year certified Halal & & \\
<1 year & 9 & 5.5 \\
1-3 years & 55 & 33.7 \\
4-6 years & 26 & 16.0 \\
7- 10 years & 31 & 19.0 \\
>10 years & 28 & 17.2 \\
Not stated & 14 & 8.6 \\
Food Quality/Safety Certification & & \\
ISO 9001 & 34 & 20.9 \\
MeSTI & 97 & 59.5 \\
GMP & 45 & 27.6 \\
HACCP/ISO 2200 & 56 & 34.4 \\
Others, please specify: & 38 & 23.3 \\
No. of employee & & \\
$<5$ & 25 & 15.3 \\
5-75 & 103 & 63.2 \\
>75 -200 & 35 & 21.5 \\
No of product & & \\
1-10 & 71 & 43.6 \\
11-50 & 57 & 35.0 \\
51-99 & 12 & 7.4 \\
>100 & 23 & 14.1 \\
\hline
\end{tabular}

\section{Correlation}

The non-parametric test of Spearman correlation results is presented in Table 2. The results showed that all Halal food management system critical constructs were positively and significantly correlated $(p<0.01)$ with each other. The coefficient range between 0.547 to 0.788 indicating strong relationship (Cohen, 1977). The coefficient values, however, were less than 0.80 , indicating multicollinearity may not impose problems in the analysis (Katz, 2011). To further examine the possibility of multicollinearity, variance inflation factor (VIF) values were inspected. As depicted in Table 2 all VIF were below 10 as suggested by Kline (2011); indicating no multicollinearity problem in the data.

Table 2: Correlations and Variance Inflation Factor (VIF)

\begin{tabular}{lllllllllll}
\hline Construct & F1 & F2 & F3 & F4 & F5 & F6 & F7 & F8 & F9 & VIF \\
\hline
\end{tabular}


INTERNATIONAL JOURNAL OF ACADEMIC RESEARCH IN BUSINESS AND SOCIAL SCIENCES Vol. 10, No. 3, March, 2020, E-ISSN: 2222-6990 @ 2020 HRMARS

\begin{tabular}{|c|c|c|c|c|c|c|c|c|c|c|}
\hline $\mathrm{F} 1$ & 1.000 & & & & & & & & & 4.139 \\
\hline $\mathrm{F} 2$ & $.625^{* *}$ & 1.000 & & & & & & & & 2.807 \\
\hline F3 & $.647^{* *}$ & $.716^{* *}$ & 1.000 & & & & & & & 3.72 \\
\hline $\mathrm{F} 4$ & $.788^{* *}$ & $.613^{* *}$ & $.664^{* *}$ & 1.000 & & & & & & 3.351 \\
\hline F5 & $.548^{* *}$ & $.638^{* *}$ & $.616^{* *}$ & $.556^{* *}$ & 1.000 & & & & & .46 \\
\hline F6 & $.757^{* *}$ & $.681^{* *}$ & $.721^{* *}$ & $.728^{* *}$ & $.637^{* *}$ & 1.000 & & & & 4.30 \\
\hline F7 & $.766^{* *}$ & $.587^{* *}$ & $.675^{* *}$ & $.767^{* *}$ & $.628^{* *}$ & $.716^{* *}$ & 1.000 & & & 3.66 \\
\hline F8 & $.758^{* *}$ & $.671^{* *}$ & $.726^{* *}$ & $.693^{* *}$ & $.614^{* *}$ & $.698^{* *}$ & $.721^{* *}$ & 1.000 & . & 4.35 \\
\hline F9 & $.630^{* *}$ & $.676^{* *}$ & $.643^{* *}$ & $.623^{* *}$ & $.611^{* *}$ & $.750^{* *}$ & $.547^{* *}$ & $.690^{* *}$ & 1.000 & \\
\hline
\end{tabular}

**All correlations are significant at the 0.01 level (2-tailed). F1: Management and environmental support; F2: Consumer focus; F3: Employee attributes and management F4: Teamwork; F5: Information capacity; F6: Training, policy and procedure; F7: Halal personnel empowerment; F8: Supplier management; F9: Supplier assessment

Correlation matrix is also informative to assess the impact of common method variances (CMV). A considerably large correlation $(r>0.9)$ between constructs indicates that the CMV is likely to be present in the study (Bagozzi, Yi, \& Phillips, 1991; Tehseen, Ramayah, \& Sajilan, 2017). Results obtained in Table 2 suggest a lack of concern for the CMV. All the correlations among the independent constructs were positive and statistically significant. This trend is also observed in previous quality management system studies (Ahire, Golhar, \& Waller, 1996; Dow et al., 1999; Issac, Rajendran, \& Anantharaman, 2004; Rungtusanatham, Salvador, Forza, \& Choi, 2003; Samson \& Terziovski, 1999; Saraph, Benson, \& Schroeder, 1989; Tarí, Molina, \& Castejón, 2007). These results may indicate that food companies usually implement these Halal food management system critical constructs in a combination (Ahire et al., 1996; Dow et al., 1999).

Additionally, Ahire, Golhar and Waller (1996) argue that the positive correlations among the quality management system critical constructs also indicate the presence of synergy between these independent constructs; a signal that management practices should be implemented holistically rather than piecemeal. This view represents the universalist view that considers quality management as a uni-dimensional set (or package) of practices, that is, companies cannot be selective in implementing only certain quality practices as all the constructs serve as building blocks of one concept (Bouranta et al., 2017; Deming, 1986; Prajogo \& Hong, 2008). Additionally, Arasli (2012, p.576) also points out that the success of the management system implementation is "not only depends on an arrangement of holistic, highlighting, and interrelated factors but also on the impact that any change in one of these components will have on the overall system".

Additionally, the positive interdependence may also indicates the possible existence of a secondorder relationship among some of the management system constructs (Prajogo \& Hong, 2008; Tamimi, 1998). However, the second-order model is not tested as the independent constructs in this study have unequal lower order indicators. The inequality of indicators numbers may bias the relationships between the higher order construct and lower order constructs (Becker, Klein, \& Wetzels, 2012; Hair, Hult, Ringle, \& Sarstedt, 2016).

\section{Measurement and Structural Model Evaluation}

The PLS model is analysed and interpreted in two main stages: the measurement and structural stages. Measurement model evaluation results provided evidence for convergent validity. All the 
INTERNATIONAL JOURNAL OF ACADEMIC RESEARCH IN BUSINESS AND SOCIAL SCIENCES Vol. 10, No. 3, March, 2020, E-ISSN: 2222-6990 @ 2020 HRMARS

loadings and composite reliability $(\mathrm{CR})$ values exceeded the recommended value of 0.7. AVE for all the latent constructs also exceeded 0.5, the least value recommended (Hair et al., 2013). The HTMT ratio is less than 0.90, indicating that discriminant validity is not a problem in this study (Hair et al., 2017). Following the measurement model, the standardized root mean square residual (SRMR) was used to assess the model fit. For this model the SRMR value is 0.056 , well below the 0.08 criteria (Hair et al. 2017), demonstrating a good fit of the model. Figure 1 shows the path coefficient significance level $(\beta)$, the coefficient of determination $\left(R^{2}\right)$, and cross-validated redundancy $\left(Q^{2}\right)$ (Hair, Hult, Ringle, \& Sarstedt, 2013), three main criteria to assess the structural model. Chin, Peterson and Brown (2008) categorized $R^{2}$ values as substantial $(0.67)$, moderate $(0.33)$ or weak (0.19). Based on these criteria, operational performance $\left(R^{2}=0.757\right)$ and product quality $\left(R^{2}=0.706\right)$ can be described as substantial. The result found the proposed instrument to be predictive of operational performance $\left(Q^{2}=0.475\right)$ and product quality $\left(Q^{2}=0.564\right)$. These findings indicates that the nine constructs have a reasonably high degree of predictive validity when taken together (Samson \& Terziovski, 1999).

The bootstrapping procedure (5000 iterations) indicates that not all path coefficients are significant. Only four of the nine Halal management critical constructs (consumer focus, employee attributes and management, teamwork and information capacity) had a significant positive association with operational performance. On the other hand, product quality was positively and significantly associated with only three Halal food management system critical constructs, management and environmental support, employee attributes and management, as well as supplier management. Halal personnel empowerment was significantly and negatively related to operational performance. The other remaining Halal management constructs were essentially not related to the performance outcomes. The complete results of the structural model and hypotheses testing are presented in Table 3.

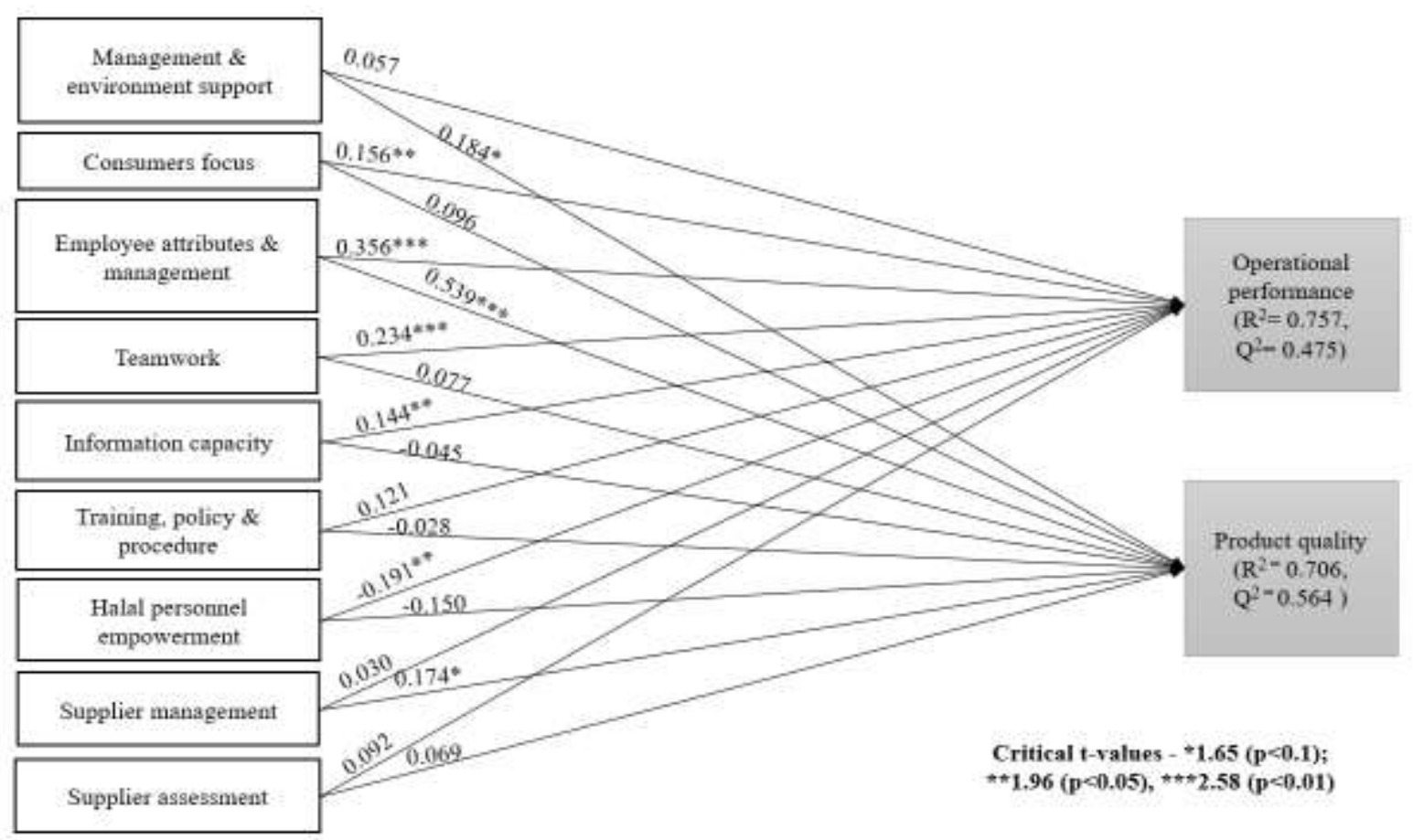


INTERNATIONAL JOURNAL OF ACADEMIC RESEARCH IN BUSINESS AND SOCIAL SCIENCES

Vol. 10, No. 3, March, 2020, E-ISSN: 2222-6990 (C) 2020 HRMARS

Figure 1: Structural Model

Table 3: Path Coefficient and Hypotheses Testing

\begin{tabular}{|c|c|c|c|c|c|c|}
\hline Hypothesis & Relationship & Beta & Error & $T$-value & $\begin{array}{l}\text { Effect } \\
\text { size, } \mathrm{f}^{2}\end{array}$ & Decision \\
\hline H1a & $\begin{array}{l}\text { F1: Management and } \\
\text { environmental support } \rightarrow \\
\text { operational performance }\end{array}$ & 0.057 & 0.091 & 0.618 & 0.003 & Reject \\
\hline $\mathrm{H} 2 \mathrm{a}$ & $\begin{array}{l}\text { F1: Management and } \\
\text { environmental support } \rightarrow \\
\text { product quality }\end{array}$ & 0.184 & 0.096 & $1.912 *$ & 0.029 & Accept \\
\hline H1b & $\begin{array}{l}\text { F2: Consumer focus } \\
\rightarrow \text { operational } \\
\text { performance }\end{array}$ & 0.156 & 0.075 & $2.08 * *$ & 0.038 & Accept \\
\hline $\mathrm{H} 2 \mathrm{~b}$ & $\begin{array}{l}\text { F2: Consumer focus } \rightarrow \\
\text { product quality }\end{array}$ & 0.096 & 0.094 & 1.018 & 0.012 & Reject \\
\hline$H 1 c$ & $\begin{array}{l}\text { F3: Employee attributes } \\
\text { and management } \rightarrow \\
\text { operational performance }\end{array}$ & 0.356 & 0.093 & $3.834^{* * *}$ & 0.148 & Accept \\
\hline $\mathrm{H} 2 \mathrm{c}$ & $\begin{array}{l}\text { F3: Employee attributes } \\
\text { and management } \rightarrow \\
\text { product quality }\end{array}$ & 0.539 & 0.087 & $6.187 * * *$ & 0.281 & Accept \\
\hline H1d & $\begin{array}{l}\text { F4: Teamwork } \rightarrow \\
\text { operational performance }\end{array}$ & 0.234 & 0.082 & $2.842^{* * *}$ & 0.071 & Accept \\
\hline $\mathrm{H} 2 \mathrm{~d}$ & $\begin{array}{l}\text { F4: Teamwork } \rightarrow \text { product } \\
\text { quality }\end{array}$ & 0.077 & 0.082 & 0.941 & 0.006 & Reject \\
\hline H1e & $\begin{array}{l}\text { F5: Information capacity } \rightarrow \\
\text { operational performance }\end{array}$ & 0.144 & 0.058 & $2.494^{* *}$ & 0.037 & Accept \\
\hline $\mathrm{H} 2 \mathrm{e}$ & $\begin{array}{l}\text { F5: Information capacity } \rightarrow \\
\text { product quality }\end{array}$ & -0.045 & 0.065 & 0.69 & 0.003 & Reject \\
\hline H1f & $\begin{array}{l}\text { F6: Training, policy and } \\
\text { procedure } \rightarrow \text { operational } \\
\text { performance }\end{array}$ & 0.121 & 0.089 & 1.353 & 0.015 & Reject \\
\hline $\mathrm{H} 2 \mathrm{f}$ & $\begin{array}{l}\text { F6: Training, policy and } \\
\text { procedure } \rightarrow \text { product } \\
\text { quality }\end{array}$ & -0.028 & 0.089 & 0.318 & 0.001 & Reject \\
\hline $\mathrm{H} 1 \mathrm{~g}$ & $\begin{array}{l}\text { F7: Halal personnel } \\
\text { empowerment } \rightarrow \\
\text { operational performance }\end{array}$ & -0.191 & 0.085 & $2.244^{* *}$ & 0.043 & Reject \\
\hline $\mathrm{H} 2 \mathrm{~g}$ & $\begin{array}{l}\text { F7: Halal personnel } \\
\text { empowerment } \rightarrow \text { product } \\
\text { quality }\end{array}$ & -0.150 & 0.106 & 1.42 & 0.022 & Reject \\
\hline
\end{tabular}


INTERNATIONAL JOURNAL OF ACADEMIC RESEARCH IN BUSINESS AND SOCIAL SCIENCES Vol. 10, No. 3, March, 2020, E-ISSN: 2222-6990 @ 2020 HRMARS

\begin{tabular}{|c|c|c|c|c|c|c|}
\hline Hypothesis & Relationship & Beta & Error & T-value & $\begin{array}{l}\text { Effect } \\
\text { size, } f^{2}\end{array}$ & Decision \\
\hline H1h & $\begin{array}{lr}\text { F8: Supplier management } \\
\rightarrow & \text { operational } \\
\text { performance } & \end{array}$ & 0.030 & 0.086 & 0.345 & 0.001 & Reject \\
\hline $\mathrm{H} 2 \mathrm{~h}$ & $\begin{array}{l}\text { F8: Supplier management } \\
\rightarrow \text { product quality }\end{array}$ & 0.174 & 0.096 & $1.817^{*}$ & 0.025 & Accept \\
\hline H1i & $\begin{array}{l}\text { F9: Supplier assessment } \rightarrow \\
\text { operational performance }\end{array}$ & 0.092 & 0.076 & 1.205 & 0.013 & Reject \\
\hline $\mathrm{H} 2 \mathbf{i}$ & $\begin{array}{l}\text { F9: Supplier assessment } \rightarrow \\
\text { product quality }\end{array}$ & 0.069 & 0.065 & 1.063 & 0.006 & Reject \\
\hline
\end{tabular}

Critical t-values - *1.65 ( $p<0.1) ; * * 1.96(p<0.05), * * * 2.58(p<0.01)$; Effect size $\left(f^{2}\right): 0.02$-small effects, 0.15 - medium effects, 0.35 - large effects

The results of hypotheses testing (Table 3) revealed both expected and less expected findings, shedding valuable insights for Halal researchers. From the results, it is apparent that some critical constructs are more significant than others in improving specific performance constructs of a food company. The findings found that only four of nine independent constructs were positively and significantly correlated with operational performance. These four factors are consumer focus, employee attributes and management, teamwork and information capacity. The positive relationships between these constructs have also been reported in previous quality management literature. For example, effective customer focus efforts was also positively associated with operational performance in a study conducted by Sadikoglu and Olcay (2014). While the information capacity construct in this study is not exactly similar to a construct tested by Othman, Md. Shaarani and Bahron (2017), the previous authors also found that sensitivity to the Halal policy issued by the government had a positive and significant relationship with organisational performance.

Product quality is affected by three out of the nine critical constructs, namely management and environmental support, supplier management and employee attributes and management. As expected, effective supplier management improves conformance of quality performance of the buyer companies (Yang, Wong, Lai, \& Ngome, 2009), by means of high-quality inputs deliver high-quality products (Sadikoglu \& Zehir, 2010). Additionally, the importance of linking the top management and the overall environmental support in improving product quality is also highlighted in the study of Cheung and To (2010).

Employee attributes and management is the only construct proved to be significant and positively related to both operational performance and product quality. The importance of employee in influencing the effectiveness of management system has also been cited by multiple authors (Bhuiyan \& Alam, 2005; Feng et al., 2008; Magd, 2008). Well trained employees help improve the quality, reliability, and timely delivery of the products (Sadikoglu \& Olcay, 2014). Specifically, Din and Rajadurai (2013) also found that employees, in term of their commitment to be significantly related to successful implementation of Halal food management system.

Other Halal food management system critical constructs do not appear to have any significant relation to operational performance and product quality. These results do not appear to be exclusive to Halal context; previous quality management literature also found comparable results (Bouranta et 
INTERNATIONAL JOURNAL OF ACADEMIC RESEARCH IN BUSINESS AND SOCIAL SCIENCES Vol. 10, No. 3, March, 2020, E-ISSN: 2222-6990 @ 2020 HRMARS

al., 2017; Dow et al., 1999; Psomas \& Jaca, 2016; Samson \& Terziovski, 1999). For example, Powell (1995) found that only three of 12 quality management factors were significantly correlated with overall organisational performance. Similarly, a more recent study by Psomas and Jaca (2016) also found that not all five quality management constructs tested contribute equally to the operational performance and product/service quality.

There are several possible explanations for these non-significant results. First, the insignificant relationship between Halal food management system critical constructs and performance may indicate the existence of indirect or nonlinear relationship, implying mediational relationships among Halal food management system critical constructs. The previous studies have also found that although in general quality management practices are positively correlated with performance, their relationship may be direct or indirect (Flynn \& Schroeder, 1995; Kaynak, 2003; Sadikoglu \& Olcay, 2014; Tarí et al., 2007). Kaynak (2003) found that leadership indirectly affects organisational performance through the mediating effects of the other quality management practices such as supplier quality management, training, employee relations, quality data and reporting, product/service design and process management.

A possible explanation for the non-significant findings might be that different Halal food management system critical constructs may have direct relationships with different type of performance constructs as indicated in previous quality management literature (Albers Mohrman, Tenkasi, Lawler, \& Ledford, 1995; Sadikoglu \& Olcay, 2014; Sadikoglu \& Zehir, 2010). For example, Anderson, Jerman and Crum (1998) found that leadership had direct effect on human resource focus and benchmarking, but not on operational performance. On the other hand, Sadikoglu and Olcay (2014) found that knowledge and process management practices improved multiple performances such as inventory management performance, innovation performance, social responsibility, and market and financial performance. However, they found that successful supplier quality management only enhanced social responsibility construct.

A few researchers in quality management literature argue that company contexts may justify why some practices did not have a significant impact on performance (Dow et al., 1999; Ketokivi \& Schroeder, 2004; Powell, 1995; Sousa \& Voss, 2002). According to Dow et al. (1999), certain practices such as supplier relations may only important in industries where purchased components are complex, and represent a significant proportion of the final product. This viewpoint represents a contingency view, the competing view against the best practice paradigm. The proponents of best practice paradigm advocate the universally applicable of quality practices and believe that the difficulties in implementation are a part of the continuous improvement for companies towards "excellence' (Sousa \& Voss, 2008). The contingency and synergistic take on Halal food management system critical constructs can be an interesting subject to be explored in future research to further advance theory development in the Halal management system literature.

One of the less expected results in this study is the significant negative correlation of Halal personnel empowerment with operational performance. This result should not be used to hastily conclude that better Halal personnel empowerment leads to inferior operational performance in a company, or that companies should not empower their Halal personnel. This is because Halal personnel empowerment is deemed to be critical in ensuring effective Halal food management implementation. As previously mentioned in (Ahmad et al., 2017)given necessary authority, Halal executives may halt production, reject raw material, or stop the shipment if Halal specifications for a product or process are not met, 
INTERNATIONAL JOURNAL OF ACADEMIC RESEARCH IN BUSINESS AND SOCIAL SCIENCES Vol. 10, No. 3, March, 2020, E-ISSN: 2222-6990 @ 2020 HRMARS

thereby reducing Halal non-compliance. Therefore, instead of operational performance, Halal personnel empowerment may has a significant and positive impact on specific performance outcomes such as prevention of non-conformance and number of non-compliance reduction; dependent constructs that have been used in previous food safety study (Xiong, Liu, Chen, \& Zheng, 2017).

Moreover, the concept of empowerment has been of great interest to researchers for decades (Spreitzer, Kizilos, \& Nason, 1997). Some researchers argue that the empowerment concept has a "good fit" with certain sets of cultural values, but may be ineffectual or inapplicable in high power distance societies in countries such as China, India, and Malaysia (Davison \& Martinsons, 2002; Hui, Au, \& Fock, 2004; Luning et al., 2013). Mcfarlin (2013) however argues that the previous conclusion as an oversimplified view of a complex phenomenon. According to Fock, Hui, Au and Bond (2013), empowerment is a valuable strategy to organizations in both societies with high and low in power distance. However, more sophisticated and nuanced approaches are needed in high power distance societies, whereby the direct behavioural intervention of top managers, and "hand on" approach tend to be better received (Mcfarlin \& Coget, 2013). As such, besides employee's autonomy, selfleadership and the work environment control, managers are still required to provide support, encourage self-reinforcement, set an example, provide information and resources, as well as build trust (Liu, 2015). As indicated in previous semi-structured interviews, some informants mentioned about the thin line between trust in Halal personnel and 'hand-off' approaches by top management in handling Halal issues. Therefore, it is arguable that Halal personnel empowerment may need to be facilitated by the management support (Thamizhmanii \& Hasan, 2010). The argument on the synergy between Halal personnel empowerment and management support constructs is consistent with previous quality management literature (Kaynak, 2003; Tarí et al., 2007).

\section{Conclusion}

Although only some critical constructs were positive and significantly associated with organisational performance, companies should not only implement few significant critical constructs, especially as the main objective of Halal food management system is to ensure the Halal and Toyyib aspects of the products. Rather than piecemeal approach, companies may need to holistically and systemically implement all the critical constructs. Besides product quality and operational performance, future study should continue to develop, refine and test the models linking Halal food management system critical constructs to its specific performance outcomes. The lack of significant relationships between Halal management and performance constructs are intriguing and shall provide motivation for further investigations into potential contingencies and indirect associations of Halal food management system critical constructs on performance.

\section{Acknowledgement}

The authors would like to thank all respondents and their companies for their time and cooperation. The research is funded by Ministry of Higher Education via the Fundamental Research Grant Scheme (No. 5524577).

\section{Corresponding Author}

Ungku Fatimah Ungku Zainal Abidin

Email: ungkufatimah@upm.edu 
INTERNATIONAL JOURNAL OF ACADEMIC RESEARCH IN BUSINESS AND SOCIAL SCIENCES

Vol. 10, No. 3, March, 2020, E-ISSN: 2222-6990 @ 2020 HRMARS

\section{References}

Aggelogiannopoulos, D., Drosinos, E. H., \& Athanasopoulos, P. (2007). Implementation of a quality management system (QMS) according to the ISO 9000 family in a Greek small-sized winery : A case study. Food Control, 18, 1077-1085. https://doi.org/10.1016/j.foodcont.2006.07.010

Ahire, S., Golhar, D., \& Waller, M. (1996). Development and validation of TQM implementation constructs. Decision Sciences, 27(1), 23-56. https://doi.org/10.1111/j.15405915.1996.tb00842.x

Ahmad, A. N., Abdul Rahman, R., Othman, M., \& Abidin, U. Z. F. (2017). Critical success factors affecting the implementation of halal food management systems: Perspective of halal executives, consultants and auditors. Food Control, 74, 70-78.

https://doi.org/10.1016/j.foodcont.2016.11.031

Albers Mohrman, S., Tenkasi, R. V., Lawler, E. E., \& Ledford, G. E. (1995). Total quality management: practice and outcomes in the largest US firms. Employee Relations, 17(3), 26-41. https://doi.org/10.1108/01425459510086866

Anderson, J. C., Rungtusanatham, M., \& Schroeder, R. G. (1994). A theory of quality management underlying the Deming management method. The Academy of Management, 19(3), 472-509. https://doi.org/10.5465/AMR.1994.9412271808

Anderson, R. D., Jerman, R. E., \& Crum, M. R. (1998). Quality management influences on logistics performance. Transportation Research Part E: Logistics and Transportation Review, 34(2), 137148. https://doi.org/https://doi.org/10.1016/S1366-5545(98)00008-8

Annear, M. J., Toye, C. M., Eccleston, C. E., Mclnerney, F. J., Elliott, K. J., Tranter, B. K., ... Robinson, A. L. (2015). Dementia knowledge assessment scale: development and preliminary psychometric properties. Journal of the American Geriatrics Society, 63(11), 2375-2381.

Arasli, H. (2012). Towards business excellence in the hospitality industry: A case for 3-, 4-, and 5-star hotels in Iran. Total Quality Management \& Business Excellence, 23(5-6), 573-590. https://doi.org/10.1080/14783363.2012.669539

Bagozzi, R. P., Yi, Y., \& Phillips, L. W. (1991). Assessing Construct Validity in Organizational Research. Administrative Science Quarterly, 36(3), 421. https://doi.org/10.2307/2393203

Becker, J. M., Klein, K., \& Wetzels, M. (2012). Hierarchical latent variable models in PLS-SEM: Guidelines for using reflective-formative type models. Long Range Planning, 45, 359394. https://doi.org/10.1016/j.Irp.2012.10.001

Bedi, S. V. H. S. (2016). Are subjective business performance measures justified. International Journal of Productivity and Performance Management, 65(5), 811-830.

https://doi.org/http://dx.doi.org/10.1108/IJPPM-12-2014-0196

Bhuiyan, N., \& Alam, N. (2005). An investigation into issues related to the latest version of ISO 9000. Total Quality Management and Business Excellence, 16(2), 199-213.

Bouranta, N., Psomas, E. L., \& Pantouvakis, A. (2017). Identifying the critical determinants of TQM and their impact on company performance. The TQM Journal, 29(1), 147-166. https://doi.org/10.1108/TQM-11-2015-0142

Brah, S. A., Li Wong, J., \& Madhu Rao, B. (2000). TQM and business performance in the service sector: a Singapore study. International Journal of Operations \& Production Management, 20(11), 1293-1312. https://doi.org/https://doi.org/10.1108/01443570010348262 
INTERNATIONAL JOURNAL OF ACADEMIC RESEARCH IN BUSINESS AND SOCIAL SCIENCES

Vol. 10, No. 3, March, 2020, E-ISSN: 2222-6990 @ 2020 HRMARS

Brah, S. A., Tee, S. S. L., \& Rao, M. B. (2002). Relationship between TQM and performance of Singapore companies. International Journal of Quality \& Reliability Management, 19(4), 356379. https://doi.org/https://doi.org/10.1108/02656710210421553

Carmen, E., \& Santos-Vijande, M. L. (2014). Implementation of ISO-22000 in Spain: obstacles and key benefits. British Food Journal, 116(10), 1581-1599. https://doi.org/http://dx.doi.org/10.1108/MRR-09-2015-0216

Chen, E., Flint, S., Perry, P., Perry, M., \& Lau, R. (2015). Implementation of non-regulatory food safety management schemes in New Zealand: A survey of the food and beverage industry. Food Control, 47, 569-576. https://doi.org/10.1016/j.foodcont.2014.08.009

Cheung, M. F. Y., \& To, W. M. (2010). Management commitment to service quality and organizational outcomes. Managing Service Quality: An International Journal, 20(3), 259-272.

Chin, W. W., Peterson, R. A., \& Brown, S. P. (2008). Structural equation modeling in marketing: Some practical reminders. Journal of Marketing Theory and Practice, 16(4), 287-298.

Choi, T. Y., \& Eboch, K. (1998). The TQM paradox: relations among TQM practices, plant performance, and customer satisfaction. Journal of Operations Management, 17(1), 59-75.

Cohen, J. (1977). Statistical power analysis for the behavioral sciences (revised ed.). New York: Academic Press.

Das, A., Handfield, R. B., Calantone, R. J., \& Ghosh, S. (2000). A contingent view of quality management-the impact of international competition on quality. Decision Sciences, 31(3), 649690. https://doi.org/10.1111/j.1540-5915.2000.tb00938.x

Davison, R., \& Martinsons, M. G. (2002). Empowerment or enslavement? Information Technology \& People, 15(1), 42-59. https://doi.org/10.1108/09593840210421516

Deming, W. E. (1986). Out of the crisis. Massachusetts Institute of Technology. Center for Advanced Engineering Study, Cambridge, MA, 510.

Dess, G. G., \& Robinson Jr, R. B. (1984). Measuring organizational performance in the absence of objective measures: the case of the privately-held firm and conglomerate business unit. Strategic Management Journal, 5(3), 265-273.

Dillman, D. A., Phelps, G., Tortora, R., Swift, K., Kohrell, J., Berck, J., \& Messer, B. L. (2009). Response rate and measurement differences in mixed-mode surveys using mail, telephone, interactive voice response (IVR) and the Internet. Social Science Research, 38(1), 1-18. https://doi.org/https://doi.org/10.1016/j.ssresearch.2008.03.007

Din, R. C., \& Rajadurai, J. (2013). Linking top management commitment, employee commitment and employee sincerity to the successful implementation of Malaysian halal food standard (MS1500 : 2009) practices in Malaysia. International Conference on ISO \& TQM, 21-23. Kuching: UiTM Sarawak.

Douglas, T. J., \& Judge, W. Q. (2001). Total Quality Management implimentation and competitive advantages: The role of structural control and exploration. Academy of Management Journal, 44(1), 158-169. https://doi.org/10.2307/3069343

Dow, D., Samson, D., \& Ford, S. (1999). Exploding the myth: Do all quality management practices contribute to superior quality performance? Production and Operations Management, 8(1), 127. https://doi.org/10.1111/j.1937-5956.1999.tb00058.x

Feng, M., Terziovski, M., \& Samson, D. (2008). Relationship of ISO 9001:2000 quality system certification with operational and business performance: A survey in Australia and New Zealand- 
INTERNATIONAL JOURNAL OF ACADEMIC RESEARCH IN BUSINESS AND SOCIAL SCIENCES

Vol. 10, No. 3, March, 2020, E-ISSN: 2222-6990 @ 2020 HRMARS

based manufacturing and service companies. Journal of Manufacturing Technology Management, 19(1), 22-37. https://doi.org/10.1108/17410380810843435

Flynn, B. B., \& Schroeder, R. G. (1995). The impact of quality management practices on performance and competitive advantage. Decisions Sciences, 26(5), 659-691. https://doi.org/10.1111/j.15405915.1995.tb01445.x

Fock, H., Hui, M. K., Au, K., \& Bond, M. H. (2013). Moderation Effects of Power Distance on the Relationship Between Types of Empowerment and Employee Satisfaction. Journal of CrossCultural Psychology, 44(2), 281-298. https://doi.org/10.1177/0022022112443415

Garvin, D. A. (1987). Competing on the eight dimensions of quality. Harvard Business Review, 65(87603), 101-109. https://doi.org/10.1225/87603

Hair, J. F., Hult, G. T. M., Ringle, C. M., \& Sarstedt, M. (2016). A primer on partial least squares structural equation modeling (PLS-SEM) (2nd ed.). Washington DC: SAGE Publications.

Hair, J. F., Hult, M. G. T., Ringle, C. M., \& Sarstedt, M. (2013). A primer on partial least squares structural equation modeling (PLS-SEM). California: SAGE Publications.

Harrington, D. (2009). Confirmatory Factor Analysis.(Pocket Guides to Social Work Research Methods Series). New York: Oxford University Press.

Ho, D. C. K., Duffy, V. G., \& Shih, H. M. (2001). Total quality management: An empirical test for mediation effect. International Journal of Production Research, 39(3), 529-548. https://doi.org/10.1080/00207540010005709

Hui, M. K., Au, K., \& Fock, H. (2004). Empowerment effects across cultures. Journal of International Business Studies, 35(1), 46-60. https://doi.org/https://doi.org/10.1057/palgrave.jibs.8400067

Issac, G., Rajendran, C., \& Anantharaman, R. N. (2004). A conceptual framework for total quality management in software organizations. Total Quality Management \& Business Excellence, 15(3), 307-344. https://doi.org/https://doi.org/10.1080/1478336042000183398

Jang, W. Y., \& Lin, C. I. (2008). An integrated framework for ISO 9000 motivation, depth of ISO implementation and firm performance: The case of Taiwan. Journal of Manufacturing Technology Management, 19(2), 194-216. https://doi.org/10.1108/17410380810847918

Kafetzopoulos, D. P., \& Gotzamani, K. D. (2014). Critical factors, food quality management and organizational performance. Food Control, 40, 1-11.

https://doi.org/10.1016/j.foodcont.2013.11.029

Katz, M. H. (2011). Multivariable Analysis: A Practical Guide for Clinicians and Public Health Researchers. Cambridge: Cambridge University Press.

Kaynak, H. (2003). The relationship between total quality management practices and their effects on firm performance. Journal of Operations Management, 21(4), 405-435. https://doi.org/10.1016/S0272-6963(03)00004-4

Ketokivi, M. A., \& Schroeder, R. G. (2003). Strategic, structural-contingency and institutional explanations in the diffusion of innovative manufacturing practices. Journal of Operations Management, 22(1), 1-46. https://doi.org/http://dx.doi.org/10.1016/j.jom.2003.12.002

Khatri, Y., \& Collins, R. (2007). Impact and status of HACCP in the Australian meat industry. British Food Journal, 109(5), 343-354. https://doi.org/10.1108/00070700710746768

Kline, R. B. (2011). Principles and Practice of Structural Equation Modeling. New York: The Guilford Press.

Koc, T. (2007). The impact of ISO 9000 quality management systems on manufacturing. Journal of 
INTERNATIONAL JOURNAL OF ACADEMIC RESEARCH IN BUSINESS AND SOCIAL SCIENCES

Vol. 10, No. 3, March, 2020, E-ISSN: 2222-6990 @ 2020 HRMARS

Materials Processing Technology, 186(December 2006), 207-213.

https://doi.org/10.1016/j.jmatprotec.2006.12.034

Liao, H. T., Enke, D., \& Wiebe, H. (2004). An expert advisory system for the ISO 9001 quality system. Expert Systems with Applications, 27(2), 313-322. https://doi.org/10.1016/j.eswa.2004.02.006

Liu, Y. (2015). The review of empowerment leadership. Open Journal of Business and Management Open Journal of Business and Manage-Ment, 3(3), 476-482.

https://doi.org/10.4236/ojbm.2015.34049

Luning, P. A., Kirezieva, K., Hagelaar, G., Rovira, J., Uyttendaele, M., \& Jacxsens, L. (2013). Performance assessment of food safety management systems in animal-based food companies in view of their context characteristics: A European study. Food Control, 1-12. https://doi.org/10.1016/j.foodcont.2013.09.009

Magd, H. (2006). An investigation of ISO 9000 adoption in Saudi Arabia. Managerial Auditing Journal, 21(2), 132-147. https://doi.org/https://doi.org/10.1108/02686900610639284

Magd, H. (2008). ISO 9001: 2000 in the Egyptian manufacturing sector: perceptions and perspectives. International Journal of Quality \& Reliability Management, 25(2), 173-200. https://doi.org/https://doi.org/10.1108/02656710810846934

Mcfarlin, D., \& Coget, J. F. (2013). How does empowerment work in high and low power-distance cultures? Academy of Management Perspectives, 27(2). https://doi.org/10.5465/amp.2013.0063

Othman, B., Md. Shaarani, S., \& Bahron, A. (2017). The influence of knowledge, attitude and sensitivity to government policies in halal certification process on organizational performance. Journal of Islamic Marketing, 8(3), 393-408. https://doi.org/10.1108/JIMA-09-2015-0067

Powell, T. C. (1995). Total Quality Management as Competitive Advantage: A Review and Emperical Study. Strategic Management Journal, 16(1), 15-37.

Prajogo, D. I., \& Hong, S. W. (2008). The effect of TQM on performance in R\&D environments: A perspective from South Korean firms. Technovation, 28(12), 855-863. https://doi.org/10.1016/j.technovation.2008.06.001

Prajogo, D. I., \& Sohal, A. S. (2003). The relationship between TQM practices, quality performance, and innovation performance: An empirical examination. International Journal of Quality \& Reliability Management, 20(8), 901-918. https://doi.org/10.1108/02656710310493625

Psomas, E. L., \& Jaca, C. (2016). The impact of total quality management on financial performance: Evidence from Spain. International Journal of Quality \& Reliability Management, 33(3). https://doi.org/10.1108/IJQRM-07-2014-0090

Psomas, E. L., Pantouvakis, A., \& Kafetzopoulos, D. P. (2013). The impact of ISO 9001 effectiveness on the performance of service companies. Managing Service Quality: An International Journal, 23(2), 149-164. https://doi.org/10.1108/09604521311303426

Razalli, M. R., Yusoff, R. Z., \& Roslan, M. W. M. (2013). A framework of halal certification practices for hotel industry. Asian Social Science, 9(11), 316-326. https://doi.org/10.5539/ass.v9n11p316

Rungtusanatham, M., Salvador, F., Forza, C., \& Choi, T. Y. (2003). Supply-chain linkages and operational performance: A resource-based-view perspective. International Journal of Operations \& Production Management, 23(9), 1084-1099.

https://doi.org/10.1108/01443570310491783

Sadikoglu, E., \& Olcay, H. (2014). The effects of total quality management practices on performance 
INTERNATIONAL JOURNAL OF ACADEMIC RESEARCH IN BUSINESS AND SOCIAL SCIENCES

Vol. 10, No. 3, March, 2020, E-ISSN: 2222-6990 @ 2020 HRMARS

and the reasons of and the barriers to TQM practices in Turkey. Advances in Decision Sciences, 2014. https://doi.org/10.1155/2014/537605

Sadikoglu, E., \& Zehir, C. (2010). Investigating the effects of innovation and employee performance on the relationship between total quality management practices and firm performance: An empirical study of Turkish firms. International Journal of Production Economics, 127(1), 13-26. https://doi.org/10.1016/j.ijpe.2010.02.013

Samson, D., \& Terziovski, M. (1999). The relationship between total quality management practices and operational performance. Journal of Operations Management, 17(4), 393-409. https://doi.org/10.1016/S0272-6963(98)00046-1

Saraph, J. V., Benson, P. G., \& Schroeder, R. G. (1989). An Instrument for Measuring the Critical Factors of Quality Management. Decision Sciences, 20(4), 810-829. https://doi.org/10.1111/j.1540-5915.1989.tb01421.x

Scott, B. S., Wilcock, A. E., \& Kanetkar, V. (2009). A survey of structured continuous improvement programs in the Canadian food sector. Food Control, 20(3), 209-217. https://doi.org/10.1016/j.foodcont.2008.04.008

Semos, A., \& Kontogeorgos, A. (2007). HACCP implementation in northern Greece: Food companies' perception of costs and benefits. British Food Journal, Vol. 109, pp. 5-19. https://doi.org/10.1108/00070700710718471

Shah, R., \& Ward, P. T. (2007). Defining and developing measures of lean production. Journal of Operations Management, 25(4), 785-805. https://doi.org/10.1016/j.jom.2007.01.019

Sila, I. (2007). Examining the effects of contextual factors on TQM and performance through the lens of organizational theories: An empirical study. Journal of Operations Management, 25(1), 83109. https://doi.org/10.1016/j.jom.2006.02.003

Sousa, R., \& Voss, C. A. (2002). Quality management re-visited: a reflective review and agenda for future research. In Journal of Operations Management (Vol. 20, pp. 91-109). https://doi.org/https://doi.org/10.1016/S0272-6963(01)00088-2

Sousa, R., \& Voss, C. A. (2008). Contingency research in operations management practices. Journal of Operations Management, 26(6), 697-713. https://doi.org/10.1016/j.jom.2008.06.001

Spreitzer, G. M., Kizilos, M. A., \& Nason, S. W. (1997). A dimensional analysis of the relationship between psychological empowerment and effectiveness, satisfaction, and strain. Journal of Management VO - 23, 23(5), p679-p679. https://doi.org/https://doi.org/10.1177/014920639702300504

Talib, M. S. A., Abdul Hamid, A. B., \& Chin, T. A. (2016). Can halal certification influence logistics performance? Journal of Islamic Marketing, 7(4), 461-475. https://doi.org/10.1108/JIMA-022015-0015

Talib, M. S. A., Ai Chin, T., \& Fischer, J. (2017). Linking Halal food certification and business performance. British Food Journal, 119(7), BFJ-01-2017-0019. https://doi.org/10.1108/BFJ-012017-0019

Tamimi, N. (1998). A second order factor analysis of critical TQM factors. International Journal of Quality and Reliability Management, 14(1), 71-79.

https://doi.org/https://doi.org/10.1108/13598539810196886

Tarí, J. J., Molina, J. F., \& Castejón, J. L. (2007). The relationship between quality management practices and their effects on quality outcomes. European Journal of Operational Research, 
INTERNATIONAL JOURNAL OF ACADEMIC RESEARCH IN BUSINESS AND SOCIAL SCIENCES

Vol. 10, No. 3, March, 2020, E-ISSN: 2222-6990 @ 2020 HRMARS

183(2), 483-501. https://doi.org/10.1016/j.ejor.2006.10.016

Tehseen, S., Ramayah, T., \& Sajilan, S. (2017). Testing and Controlling for Common Method Variance: A Review of Available Methods. Journal of Management Sciences, 4(2), 142-168. https://doi.org/10.20547/jms.2014.1704202

Thamizhmanii, S., \& Hasan, S. (2010). A review on an employee empowerment in TQM practice. Manufacturing Engineering, 39(2), 204-210.

Trienekens, J., \& Zuurbier, P. (2008). Quality and safety standards in the food industry, developments and challenges. International Journal of Production Economics, 113(1), 107-122. https://doi.org/10.1016/j.ijpe.2007.02.050

Wall, T. D., Michie, J., Patterson, M., Wood, S. J., Sheehan, M., Clegg, C. W., \& West, M. (2004). On the validity of subjective measures of company performance. Personnel Psychology, 57(1), 95118.

Xiong, C., Liu, C., Chen, F., \& Zheng, L. (2017). Performance assessment of food safety management system in the pork slaughter plants of China. Food Control, 71, 264-272. https://doi.org/10.1016/j.foodcont.2016.07.006

Yang, J., Wong, C. W. Y., Lai, K., \& Ngome, A. (2009). Int . J . Production Economics The antecedents of dyadic quality performance and its effect on buyer - supplier relationship improvement. Intern. Journal of Production Economics, 120(1), 243-251.

https://doi.org/10.1016/j.ijpe.2008.07.033 